\title{
The Effectiveness of Video Distraction on Children Preoperative Anxiety: An Integrative Literature Review
}

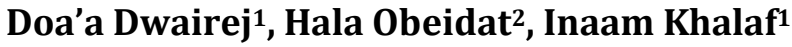 \\ ${ }^{1}$ School of Nursing, The University of Jordan, Amman, Jordan \\ ${ }^{2}$ Princess Muna College of Nursing, Mutah University, Amman, Jordan \\ Email: doaadwairej@yahoo.com, obeidathala@y ahoo.com, khalaf12@y ahoo.com
}

How to cite this paper: Dwairej, D., Obeidat, H. and Khalaf, I. (2018) The Effectiveness of Video Distraction on Children Preoperative Anxiety: An Integrative Literature Review. Open Journal of Nursing, 8, 171-187.

https://doi.org/10.4236/ojn.2018.83015

Received: January 15, 2018

Accepted: March 12, 2018

Published: March 15, 2018

Copyright ( $) 2018$ by authors and Scientific Research Publishing Inc. This work is licensed under the Creative Commons Attribution International License (CC BY 4.0).

http://creativecommons.org/licenses/by/4.0/

c) (i) Open Access

\begin{abstract}
Background: Children who undergo a day case surgery experience high levels of preoperative anxiety. Preoperative anxiety interferes with anesthesia induction compliance and is associated with many short and long term postoperative complications. Recently, video distraction intervention has been evaluated for its anxiolytic effects in preoperative children. Aim: The aim of this integrative review was to demonstrate the varying methodological approaches utilized to evaluate the effectiveness of a video distraction intervention in reducing preoperative anxiety in children undergoing day case surgery. Methods: A total of 8 articles, meeting the inclusion criteria, were evaluated and included. Findings: The eight studies investigating the effect of video distraction on children preoperative anxiety concluded that video distraction was significant in controlling children preoperative anxiety. Four of the eight studies (50\%), investigated video distraction effectiveness against pharmacological comparisons and demonstrated superior or equal anxiolytic effect of video distraction on different points along the surgical continuum. Three of the eight studies compared video distraction against parental presences and video distraction showed superior anxiolytic effect. Three of the eight studies evaluated the effect of video distraction on anesthesia induction compliance and emergence delirium. A significant effect on anesthesia induction was demonstrated while non-significant effect on emergence delirium was documented. Conclusion: Video distraction is a safe, time and cost effective non pharmacological anxiolytic intervention. It can be provided by nurses to control children high level of anxiety before surgery and during anesthesia induction.
\end{abstract}

\section{Keywords}

Video Distraction, Preoperative Anxiety, Children, Anesthesia Induction 


\section{Introduction}

The event of surgery carries an enormous amount of anxiety for children [1]. Children usually approach the surgery with high level of anxiety which exacerbate at the time of anesthesia induction [2]. Parental separation is another critical moment at child's surgical continuum; children experience high level of anxiety at this point of time [3]. Separation anxiety, unfamiliar environment with strange personnel and different routines, loss of control and fear from injury, mutilation or death are among the sources of children preoperative anxiety [4].

Preoperative anxiety is associated with multiple complications that might develop immediately after surgery or thereafter. It is associated with lower anesthesia induction compliance [5], higher postoperative pain, increased analgesic consumption and higher rates of emergence delirium [2] [6]. It is also related with postoperative maladaptive behaviors such as sleeping and eating disturbances [7]. Non-compliant children are very resistant to anesthesia induction; they scream loudly and they occasionally need to be restrained by staff during the induction [5]. Physiologically, the levels of blood cortisol heighten as a result of stress response that is associated with surgical anxiety [8]. This in turn might increase the risk of infection and delay healing postoperatively [8].

To overcome the plethora of consequences of preoperative anxiety, many pharmacological and nonpharmacologic anxiolytic interventions have been evaluated for their effectiveness [1] [3]. However, the nonpharmacological anxiolytic interventions are increasingly replacing the pharmacological ones because of their superior or equal effect [9]. Nonpharmacological anxiolytic interventions range from complex multicomponent behavioral programs [10] to simple interventions such as playing with toys [11]. Within the rapid pace working rhythm in the day case surgery units, multicomponent programs have been criticized for being time and cost consuming [12]. Therefore, mounting amount of literature is directed toward addressing the effectiveness of simple and brief behavioral anxiolytic interventions.

Distraction techniques such as the use of humor and various playful activities are common non pharmacological anxiolytic interventions [13]. Distraction is defined as diverting the attention away from the stressful stimuli toward a non-stressful behavior or thought [14]. In this era, the technology have provided a new platform for preoperative anxiety management; It has provided new tools for distraction [15].Within hospital settings, the hand held devices such as tablets are wildly used to distract children through anxiety and pain provoking procedures [16]. Different Audiovisual preoperative distraction interventions have been found to be effective in reducing children preoperative anxiety [17]. Video games have global popularity and attract wide array of pop- 
ulation with different sociodemographic characteristics [18]. Primack and colleagues highlighted the potential role of video games in improving health outcomes [19]. Recently, there is an increasing amount of literature that is directed toward investigating the effectiveness of video distraction in controlling the children preoperative anxiety. Video distraction interventions have been compared against various pharmacological and nonpharmacological anxiety reduction interventions.

Yet, the best practice in relation to preoperative anxiety management in children has not been reached [20]. Therefore, such type of reviews which aim to synthesis the literature regarding a preoperative anxiety management approach constitute a step further toward reaching a consensus about the best practice in the field of preoperative preparation. This review contributed to identify the research gaps regarding video distraction and its effect on children preoperative anxiety. It has also contributed to provide a practical recommendation about the best practice in implementing the video distraction for minimizing children preoperative anxiety.

\section{Purpose of the Review}

The purpose of this integrative literature review is to demonstrate the different methodological approaches utilized to evaluate the effectiveness of a video distraction intervention in reducing preoperative anxiety in children. It will examine the various video distraction interventions employed and the strength of the evidence supporting use of a video distraction intervention, and determine whether the intervention successfully demonstrated decreased levels of anxiety, anesthesia induction compliance and emergence delirium in preoperative children.

\section{Review Question}

What is the effectiveness of video game distraction on children preoperative anxiety, anesthesia induction compliance and emergence delirium?

\section{Methods}

To prepare this integrative literature review, the authors followed the Preferred Reporting Item for Systematic reviews and Meta-analysis statement (PRISMA) guidelines [21].

\subsection{Eligibility Criteria}

The authors have used Participants, Interventions, Comparisons, Outcome and Study design approach (PICOS) [22] to formulate the guiding question of the current review. The approach has also guided the authors in identifying the eligibility criteria. We looked for both randomized and non-randomized clinical trials that included children under the age of 18 who underwent a day case surgery under general anesthesia. Additionally, the studies were included if a video distraction was provided as an intervention. The included studies have at least 
one control or comparison group and reported the children preoperative anxiety as its end point outcome.

Video game intervention was defined as any type of passive (watching film or cartoon) or active video distraction (interactive video games) provided through any device (i.e. tablet or smart phone). The control groups in the included studies were groups that received the standard preparation or any other pharmacological or non-pharmacological anxiolytic comparison intervention.

\subsection{Information Source and Search}

The following data bases were systematically searched: EBESCO, Pubmed, Scopus and MEDLINE. Ancestry and descendancy review was carried out to determine additional resources. The electronic data bases were searched for the following keywords: "video distraction"; "audiovisual distraction"; "cartoon distraction"; "preoperative anxiety". These key words were searched independently and they were combined using different Boolean operators (i.e. AND/OR). The reviewer developed the search strategy and strategy was followed in all databases. The studies that were published in English language from the year of 2005-2017 were searched using the defined key words. Editorials, books and unpublished papers were excluded from the search.

\subsection{Study Selection}

The study selection was performed by the main author. The duplications were removed and the remaining studies' titles and abstracts were screened; after excluding the irrelevant studies, the remaining potential relevant studies were compared against the eligibility criteria and only 8 studies were included for the final review.

\subsection{Data Collection Process}

A data extraction form was developed and was used to collect the required information from the eligible studies. The data regarding the study design, the participants characteristics (number of participants, type of the surgery and their age), the type of video distraction intervention (passive vs. active), details about the intervention, the comparison group(s), the data collection measures that were used to evaluate the primary and secondary outcomes, data collection points, and the study results in relation to the primary and secondary outcomes were extracted using the data extraction form. The primary outcome was the children's preoperative anxiety and the secondary outcomes were the anesthesia induction compliance and emergence delirium. The data was extracted from each study independently.

\subsection{Data Collection Process}

The risk of bias for each individual study was evaluated based on the Cochran risk of bias tool for randomized clinical trials [22]. The criteria to evaluate the 
risk of bias include the following items: random sequence generation and allocation concealment to evaluate the risk of selection bias; selective reporting to evaluate the risk of reporting bias; blinding of personnel and participants to evaluate the performance bias; blinding of the outcome assessment to evaluate the detection bias; incomplete outcome data to evaluate the attrition bias. Based on the guidelines, each item is judged as: low risk, high risk or unclear risk of bias [22].

\section{Results}

\subsection{Study Selection}

Through searching the data bases, 1270 studies were identified. We found an additional study through ancestry search. After removing the duplicates 871 studies were assessed for their relevance to the current review purpose. As a result of the initial screening 772 article were excluded. The remaining 89 full text studies were assessed for their eligibility; however 8 studies met the inclusion criteria and were included in this review. Figure 1 demonstrates the PRISMA flow diagram of the current review.

\subsection{Study Characteristics}

The major studies' characteristics in respect to the number of participants involved and their age; the type of video distraction and some details about the interventions are summarized in Table 1 . Eight studies were reviewed; in totality, the studies included 905 children who ranged in age from $1-12$ years. The studies were conducted in three developed countries; USA, South Korea, and France. It included children who underwent an outpatient or elective surgery with general anesthesia.

\subsection{Type, Duration and Selection of Video Distraction Intervention}

The majority of the reviewed studies have implemented a passive video distraction [23] [24] [25] [26] [27]. Passive distraction does not require the child to actively engage in the distraction activity such as watching a film or cartoon. While the active distraction involves active participation of the child; this involves different sensory components such as interactive electronic and videogames. In 6 studies the video distraction began in the holding area while the children were waiting their surgery and the video distraction continued until the children fell in sleep during anesthesia induction [23] [24] [25] [27] [28] [29]. While Mifflin et al. [26] started the video distraction during the anesthesia induction and Seiden et al. [30] began the distraction at the time of parental separation before surgery. The studies were similar in term of video distraction selection; all 8 studies reported that he children were able to self-select the game that they wanted to play with or the film that they wanted to watch. 


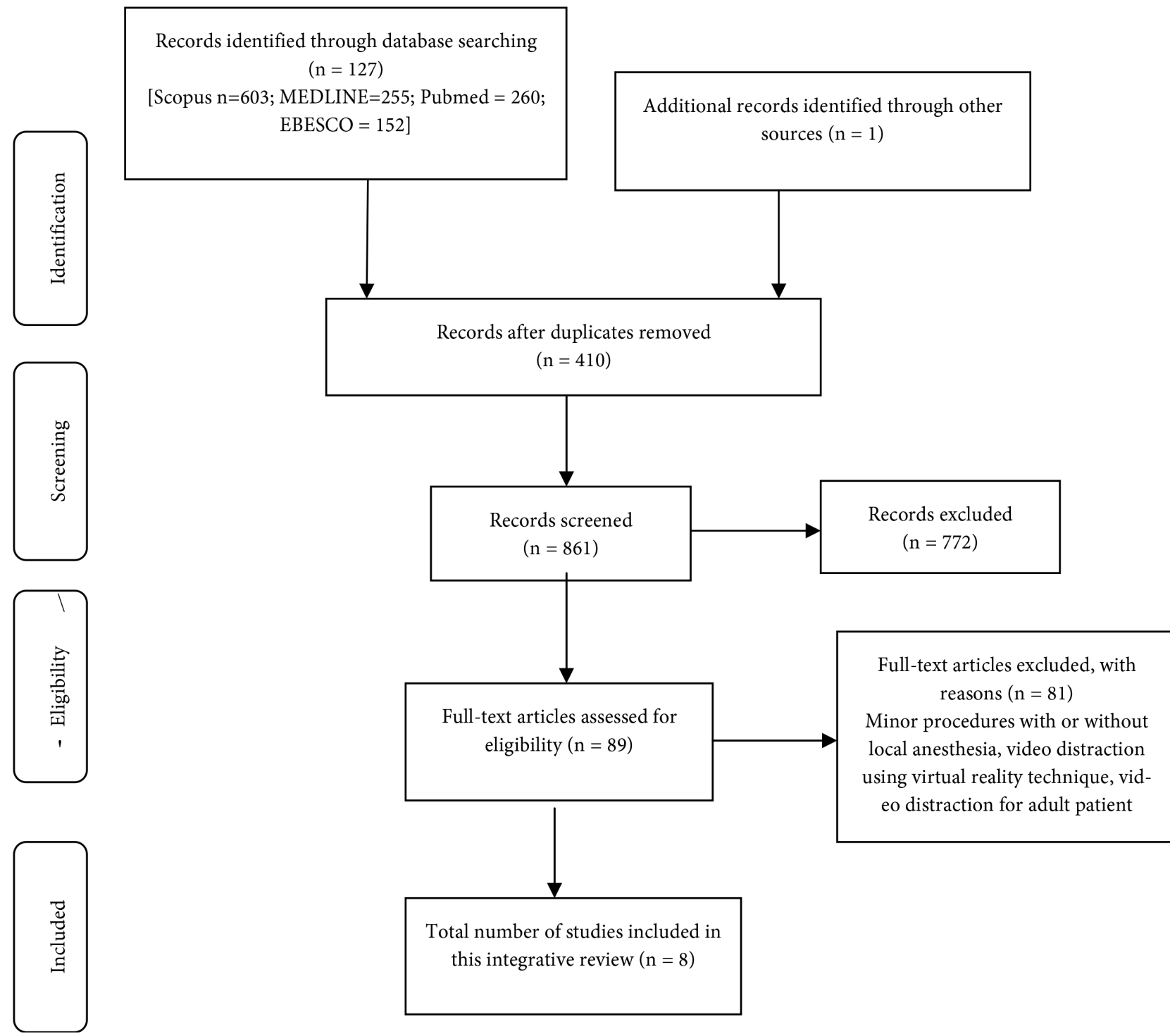

Figure 1. PRISMA flow chart for the current review.

\subsection{The effectiveness of Video Distraction Intervention versus Non Pharmacological Comparison(s) in Minimizing Preoperative Anxiety ( $\mathrm{n}=3)$}

The studies that compared video distraction intervention with nonpharmacological interventions included comparisons such as: traditional toys playing and standard care comparisons [25]; standard care comparison [26]; parental presence and combined parental presence and video distraction comparisons [23]. The baseline equivalence in term of the level of anxiety was reported in the three studies. However, the children in the video distraction groups in all 3 studies demonstrated significantly lower level of preoperative anxiety at the time of anesthesia induction. Table 2 includes studies that demonstrated the effectiveness of video distraction intervention compared with different comparison groups. All authors used mYPAS to measure children preoperative anxiety. 
Table 1. Study characteristics.

\begin{tabular}{|c|c|c|c|c|c|}
\hline $\begin{array}{c}\text { Study } \\
\text { (authors, year), } \\
\text { country }\end{array}$ & Study design & $\begin{array}{l}\text { Participants } \mathrm{N}, \\
\text { age }\end{array}$ & Surgery types & $\begin{array}{l}\text { Video distraction } \\
\text { intervention }\end{array}$ & Intervention details \\
\hline $\begin{array}{l}\text { Patel et al. (2006), } \\
\text { USA }\end{array}$ & RCT & $\begin{array}{c}\mathrm{N}=112,4-12 \\
\text { years }\end{array}$ & $\begin{array}{l}\text { Outpatient surgery with } \\
\text { general anesthesia }\end{array}$ & $\begin{array}{l}\text { Playing a video } \\
\text { game } \\
\text { (active distraction) }\end{array}$ & $\begin{array}{l}\text { The children selected a video game to } \\
\text { play within the holding area. The } \\
\text { children began to play the game via } \\
\text { hand held tablet at least } 20 \text { minutes } \\
\text { before anesthesia and they were } \\
\text { allowed to continue playing during } \\
\text { anesthesia induction. }\end{array}$ \\
\hline $\begin{array}{l}\text { Lee et a., (2012), } \\
\text { South Korea }\end{array}$ & RCT & $\begin{array}{c}\mathrm{N}=130,3-7 \\
\text { years }\end{array}$ & $\begin{array}{c}\text { First time Elective surgery } \\
\text { with general anesthesia (eye } \\
\text { surgery, tonsillectomy, } \\
\text { herniorrhaphy hand } \\
\text { surgery) }\end{array}$ & $\begin{array}{l}\text { Watching cartoon } \\
\text { film } \\
\text { (passive distraction) }\end{array}$ & $\begin{array}{l}\text { The children selected a film in the } \\
\text { holding area and they watched it } \\
\text { (via tablet or notebook) until they fell } \\
\text { in sleep after anesthesia induction. }\end{array}$ \\
\hline $\begin{array}{l}\text { Mifflin et al., } \\
\text { (2012), USA }\end{array}$ & RCT & $\begin{array}{c}\mathrm{N}=89,2-10 \\
\text { years }\end{array}$ & $\begin{array}{l}\text { First time Ambulatory } \\
\text { surgery with general } \\
\text { anesthesia (ear, nose and } \\
\text { throat, urology surgery, } \\
\text { dentistry and general } \\
\text { surgeries) }\end{array}$ & $\begin{array}{l}\text { Watching a cartoon } \\
\text { film } \\
\text { (passive distraction) }\end{array}$ & $\begin{array}{l}\text { The children selected a video clip that } \\
\text { they usually enjoy watching and it } \\
\text { was viewed for them to watch during } \\
\text { anesthesia induction via large screens } \\
\text { in the OR. }\end{array}$ \\
\hline $\begin{array}{l}\text { Kerimoglu et al., } \\
\text { (2013), USA }\end{array}$ & RCT & $\begin{array}{c}\mathrm{N}=96,4-9 \\
\text { years }\end{array}$ & $\begin{array}{l}\text { Outpatient surgery with } \\
\text { general anesthesia }\end{array}$ & $\begin{array}{c}\text { Watching a } \\
\text { television program } \\
\text { (passive distraction) }\end{array}$ & $\begin{array}{l}\text { The children selected an age } \\
\text { appropriate television program and it } \\
\text { was viewed for them through a video } \\
\text { glass in the holding area and } \\
\text { throughout anesthesia induction. }\end{array}$ \\
\hline $\begin{array}{l}\text { Seiden et al., } \\
\text { (2014), USA }\end{array}$ & $\begin{array}{l}\text { Non inferiority } \\
\text { randomized trial }\end{array}$ & $\begin{array}{c}\mathrm{N}=108,1-11 \\
\text { years }\end{array}$ & $\begin{array}{l}\text { Outpatient surgeries with } \\
\text { general anesthesia }\end{array}$ & $\begin{array}{l}\text { Playing interactive } \\
\text { video game } \\
\text { (active distraction) }\end{array}$ & $\begin{array}{l}\text { The children selected an age } \\
\text { appropriate video game in the } \\
\text { holding area. The tablet was returned } \\
\text { to the child to play the selected game } \\
\text { at the time of parental separation and } \\
\text { they continued playing during } \\
\text { anesthesia induction. }\end{array}$ \\
\hline $\begin{array}{l}\text { Kim et al., (2015), } \\
\text { South Korea }\end{array}$ & RCT & $\begin{array}{c}\mathrm{N}=117,2-7 \\
\text { years }\end{array}$ & $\begin{array}{l}\text { Elective minor surgery with } \\
\text { general anesthesia (eye } \\
\text { surgery, tonsillectomy, } \\
\text { herniorrhaphy, neck mass } \\
\text { excision }\end{array}$ & $\begin{array}{l}\text { Watching a cartoon } \\
\text { film } \\
\text { (passive distraction) }\end{array}$ & $\begin{array}{l}\text { The children selected their preferred } \\
\text { film and started to watch it in the } \\
\text { holding area (via smartphone). They } \\
\text { continued to watch the video during } \\
\text { anesthesia induction. }\end{array}$ \\
\hline $\begin{array}{l}\text { Sola et al., (2017), } \\
\text { France }\end{array}$ & RCT & $\begin{array}{c}\mathrm{N}=135,2-12 \\
\text { years }\end{array}$ & $\begin{array}{l}\text { Ambulatory surgery with } \\
\text { general anesthesia }\end{array}$ & $\begin{array}{l}\text { Watching a cartoon } \\
\text { film } \\
\text { (passive distraction) }\end{array}$ & $\begin{array}{l}\text { The children selected an age } \\
\text { appropriate cartoon film and began } \\
\text { to watch it } 30 \text { minutes before } \\
\text { anesthesia through a DVD player. } \\
\text { The children continued the film } \\
\text { watching until they fell asleep from } \\
\text { anesthesia. }\end{array}$ \\
\hline $\begin{array}{l}\text { Marechal et al., } \\
\text { (2017); France }\end{array}$ & RCT & $\begin{array}{c}\mathrm{N}=118,4-11 \\
\text { years }\end{array}$ & $\begin{array}{c}\text { Ambulatory surgery with } \\
\text { general anesthesia for minor } \\
\text { surgeries }\end{array}$ & $\begin{array}{l}\text { Playing a video } \\
\text { game } \\
\text { (active distraction) }\end{array}$ & $\begin{array}{l}\text { The children were allowed to select } \\
\text { their preferred video game to play via } \\
\text { electronic iPad. They began to play in } \\
\text { the holding area } 20 \text { minutes before } \\
\text { anesthesia and they were allowed to } \\
\text { continue playing until they lost their } \\
\text { consciousness during anesthesia } \\
\text { induction. }\end{array}$ \\
\hline
\end{tabular}

RCT: randomized clinical trial; N: number. 
Table 2. The effectiveness of video distraction intervention.

\begin{tabular}{|c|c|c|c|c|c|}
\hline \multirow[b]{2}{*}{$\begin{array}{c}\text { Study } \\
\text { (author, year), } \\
\text { country }\end{array}$} & \multirow[b]{2}{*}{$\begin{array}{l}\text { Intervention vs. } \\
\text { comparison group }\end{array}$} & \multirow[b]{2}{*}{ Scale(s) } & \multirow[b]{2}{*}{$\begin{array}{c}\text { Follow up } \\
\text { measurement(s) }\end{array}$} & \multicolumn{2}{|l|}{ Results } \\
\hline & & & & $\begin{array}{l}\text { Primary outcome: } \\
\text { preoperative anxiety }\end{array}$ & $\begin{array}{l}\text { Secondary outcomes: } \\
\text { anesthesia induction } \\
\text { compliance and } \\
\text { emergence delirium }\end{array}$ \\
\hline $\begin{array}{l}\text { Patel et al., } \\
\text { (2006), USA }\end{array}$ & $\begin{array}{l}\text { I: video distraction(hand } \\
\text { held video game) and } \\
\text { parental presence } \\
(\mathrm{n}=38) \\
\mathrm{C} 2 \text { : premedication with } \\
\text { midazolam and parental } \\
\text { presence }(\mathrm{n}=38) \\
\text { C: parental presence } \\
(\mathrm{n}=36)\end{array}$ & mYPAS & $\begin{array}{l}\text { Baseline upon the } \\
\text { admission to } \\
\text { ambulatory surgery } \\
\text { unit P1: during } \\
\text { anesthesia induction }\end{array}$ & $\begin{array}{l}\text { The children in midazolam group } \\
\text { and in the control group } \\
\text { experienced a significant increase } \\
\text { in their anxiety level from the } \\
\text { baseline to anesthesia induction. } \\
\text { But children in the video game } \\
\text { did not demonstrate a significant } \\
\text { increase in their level of anxiety } \\
\text { from the baseline to anesthesia } \\
\text { induction. }\end{array}$ & NM \\
\hline $\begin{array}{l}\text { Lee et al., (2012), } \\
\text { South Korea }\end{array}$ & $\begin{array}{l}\text { I: video distraction } \\
\text { (cartoon) }(\mathrm{n}=42) \\
\text { C1: playing with toy } \\
(\mathrm{n}=40) \\
\text { C2: control; standard } \\
\text { care }(\mathrm{n}=44)\end{array}$ & $\begin{array}{l}\text { mYPAS and } \\
\text { parents } \\
\text { recorded VAS }\end{array}$ & $\begin{array}{l}\text { Base line one night } \\
\text { before surgery } \\
\text { P1: In the holding area } \\
\text { P2: just before } \\
\text { anesthesia induction }\end{array}$ & $\begin{array}{l}\text { No significant difference in the } \\
\text { children level of anxiety at the } \\
\text { baseline among the three group. } \\
\text { At P1: Children who played with } \\
\text { toy reviled significantly lower } \\
\text { level of anxiety than children in } \\
\text { the both groups. } \\
\text { At P2: the children in the video } \\
\text { distraction group had lower level } \\
\text { of anxiety that the children in the } \\
\text { remaining groups. } \\
\text { the level of anxiety have } \\
\text { significantly decreased between } \\
\text { P1 and P2 for children in video } \\
\text { distraction group while it have } \\
\text { significantly increased for } \\
\text { children in control and toy } \\
\text { groups }\end{array}$ & NM \\
\hline $\begin{array}{l}\text { Mifflin et al., } \\
\text { (2012), USA }\end{array}$ & $\begin{array}{l}\text { I: video distraction } \\
\text { (film) }(\mathrm{n}=42) \\
\text { C: control; usual } \\
\text { distraction }(47)\end{array}$ & mYPAS & $\begin{array}{l}\text { Base line at the } \\
\text { holding area } \\
\text { P: during induction }\end{array}$ & $\begin{array}{l}\text { The children did not differ } \\
\text { significantly at the baseline. But } \\
\text { The children in the intervention } \\
\text { group demonstrated significantly } \\
\text { lower level of anxiety than } \\
\text { children in the control group at } \\
\text { the time of anesthesia induction. }\end{array}$ & NM \\
\hline $\begin{array}{l}\text { Kerimoglu et al., } \\
\text { (2013), USA }\end{array}$ & $\begin{array}{l}\text { I:video distraction } \\
\text { (watching film) }(\mathrm{n}=32) \\
\mathrm{C} 1 \text { : premedication with } \\
\text { midazolam }(\mathrm{n}=32) \\
\mathrm{C} 2 \text { : combined video } \\
\text { game and premedication } \\
\text { with midazolam }(\mathrm{n}=32)\end{array}$ & mYPAS & $\begin{array}{l}\text { Baseline before the } \\
\text { intervention } \\
\text { P1: at the time of } \\
\text { transfer to OR } \\
\text { P2: } 20 \text { minutes after } \\
\text { transfer to OR } \\
\text { P3: during anesthesia } \\
\text { induction }\end{array}$ & $\begin{array}{l}\text { There were no significant } \\
\text { difference in the level of anxiety } \\
\text { among the three groups at P1, P2 } \\
\text { and P3. } \\
\text { The difference in the anxiety level } \\
\text { between the baseline and the } \\
\text { induction time was not } \\
\text { significantly different among the } \\
\text { three groups. But compared with } \\
\text { the other groups, children in the } \\
\text { video distraction group } \\
\text { demonstrated non-significant } \\
\text { increment in the anxiety level } \\
\text { from P1 to P3. }\end{array}$ & NM. \\
\hline
\end{tabular}




\begin{tabular}{|c|c|c|c|c|c|}
\hline $\begin{array}{l}\text { Seiden et al., } \\
\text { (2014), USA }\end{array}$ & $\begin{array}{l}\text { I: video distraction } \\
\text { (tablet based interactive } \\
\text { distraction) }(\mathrm{n}=57) \\
\text { C: premedication with } \\
\text { oral midazolam }(\mathrm{n}=51)\end{array}$ & $\begin{array}{l}\text { mYPAS and } \\
\text { PAED }\end{array}$ & $\begin{array}{l}\text { Baseline: at the } \\
\text { holding area } \\
\text { P1: parental } \\
\text { separation } \\
\text { P2: during anesthesia } \\
\text { induction }\end{array}$ & $\begin{array}{l}\text { P1: compared with children in C } \\
\text { group children in I group } \\
\text { revealed significantly lower } \\
\text { anxiety increment from the } \\
\text { baseline to parental separation. } \\
\text { P2: for children from } 2 \text { - } 11 \text { years, } \\
\text { children in the I group revealed } \\
\text { significantly lower anxiety } \\
\text { increment from the baseline to } \\
\text { anesthesia induction when } \\
\text { compared to children in the C } \\
\text { group. However, for all children } \\
\text { (1 - 11 years) there was no } \\
\text { significant difference in the } \\
\text { anxiety increment between the } \\
\text { two groups. }\end{array}$ & $\begin{array}{l}\text { Emergence delirium } \\
\text { was measured; children } \\
\text { in the intervention } \\
\text { group demonstrated } \\
\text { significantly lower } \\
\text { absolute emergence } \\
\text { delirium score than } \\
\text { children in the control } \\
\text { group. However, when } \\
\text { it was measured as a } \\
\text { cutoff point score there } \\
\text { were no significant } \\
\text { difference in the } \\
\text { emergence delirium } \\
\text { between the two groups. }\end{array}$ \\
\hline $\begin{array}{c}\text { Kim et al., (2015), } \\
\text { South Korea }\end{array}$ & $\begin{array}{l}\text { I: video distraction } \\
(\text { film })(\mathrm{n}=39) \\
\mathrm{C} 1 \text { : parental presence } \\
(\mathrm{n}=39) \text { during } \\
\text { anesthesia induction } \\
\text { C2: video distraction and } \\
\text { parental presence } \\
(\mathrm{n}=39)\end{array}$ & $\begin{array}{l}\text { mYPAS } \\
\text { ICC }\end{array}$ & $\begin{array}{l}\text { Baseline at the holding } \\
\text { area } \\
\text { P1: on the entrance to } \\
\text { the operating room } \\
\text { P2: during anesthesia } \\
\text { induction }\end{array}$ & $\begin{array}{l}\text { The children baseline anxiety did } \\
\text { not differ significantly among the } \\
\text { three groups. } \\
\text { The difference between the } \\
\text { baseline anesthesia induction } \\
\text { anxiety level was not different } \\
\text { among the three groups. } \\
\text { Nevertheless, the children in the } \\
\text { video distraction group revealed } \\
\text { significantly lower level of anxiety } \\
\text { than children in the remaining } \\
\text { groups at both P1 and P2. }\end{array}$ & $\begin{array}{l}\text { The anesthesia } \\
\text { induction compliance } \\
\text { was measured; children } \\
\text { in the video group } \\
\text { demonstrated } \\
\text { significantly higher } \\
\text { level of compliance than } \\
\text { children in the } \\
\text { remaining groups. }\end{array}$ \\
\hline $\begin{array}{l}\text { Sola et al., (2017), } \\
\text { France }\end{array}$ & $\begin{array}{l}\text { I: video distraction } \\
(\mathrm{DVD} \text { video })(\mathrm{n}=45) \\
\text { C1: premedication with } \\
\text { oral midazolam }(\mathrm{n}=45) \\
\text { C2: combined } \\
\text { premedication and video } \\
\text { distraction }(\mathrm{n}=45)\end{array}$ & $\begin{array}{c}\text { mYPAS; VAS; } \\
\text { PAED }\end{array}$ & $\begin{array}{l}\text { Baseline upon the } \\
\text { arrival to the hospital } \\
\text { P: just after the } \\
\text { separation from } \\
\text { parents. }\end{array}$ & $\begin{array}{l}\text { The children baseline anxiety did } \\
\text { not differ significantly among the } \\
\text { three groups. } \\
\text { The change in the children level } \\
\text { of anxiety from the baseline to } \\
\text { parental separation did not } \\
\text { differ significantly among the } \\
\text { three groups. } \\
\text { The children in the three } \\
\text { group did not reveal a significant } \\
\text { increment in their anxiety } \\
\text { level from the baseline to } \\
\text { separation. }\end{array}$ & $\begin{array}{l}\text { Emergence delirium } \\
\text { was measured; The } \\
\text { children in the three } \\
\text { groups did not differ } \\
\text { significantly in the } \\
\text { occurrence of } \\
\text { emergence delirium. }\end{array}$ \\
\hline $\begin{array}{l}\text { Marechal et al., } \\
\text { (2017); France }\end{array}$ & $\begin{array}{l}\text { I: video distraction } \\
\text { (tablet game apps) } \\
(\mathrm{n}=60) \\
\text { C: premedication with } \\
\text { oral midazolam }\end{array}$ & mYPAS & $\begin{array}{l}\text { Baseline upon the } \\
\text { arrival to the } \\
\text { ambulatory surgery } \\
\text { ward } \\
\text { P1: upon the } \\
\text { separation from the } \\
\text { parents } \\
\text { P2: during anesthesia } \\
\text { induction }\end{array}$ & $\begin{array}{l}\text { The children level of anxiety did } \\
\text { not differ significantly between } \\
\text { the two groups at both P1 and P2. }\end{array}$ & NM \\
\hline
\end{tabular}

$\mathrm{N}$ : number; P: point of measurement; I: intervention; C: comparison; NM: not measured; ICC: induction compliance checklist; PAED: pediatric anesthesia emergence delirium. 


\subsection{The Effectiveness of Video Distraction Intervention versus Pharmacological Comparison(s) in Minimizing Preoperative Anxiety $(\mathrm{n}=4)$}

The studies that compared video distraction intervention with pharmacological interventions included the following comparisons: premedication group [28] [30]; premedication group and combined premedication and video distraction [23] [27]. In the four studies the children received midazolam as a premedication the dose ranged from $(0.3-0.5 \mathrm{mg} / \mathrm{kg})$. Those who compared the video distraction and premedication in combination and alone did not report a statistically significant different level of preoperative anxiety at any point of time for the children in any group. However, the studies that included only premedication comparison group demonstrated different findings. In one study the children in the video distraction group demonstrated significantly lower anxiety increment from the baseline to the parental separation and to the anesthesia induction moment [30]. In the other study the children in both groups revealed no statistically significant difference in the level of preoperative anxiety at parental separation and anesthesia induction moment [28]. All authors measured the children anxiety by mYPAS.

\subsection{The Effectiveness of Video Distraction Intervention versus Pharmacological Comparison and Nonpharmacological(s) in Minimizing Preoperative Anxiety $(n=1)$}

There was only one study that included both pharmacological and nonpharmacological comparison groups [29]. The comparison groups were: parental presence alone and combined parental presence and premedication. Compared with the two comparison groups, the children in the video distraction revealed significantly lower increment of anxiety from the base line to the anesthesia induction.

\subsection{The Effectiveness of Video Distraction Intervention on Children Anesthesia Induction Compliance and Emergence Delirium}

Anesthesia induction compliance was measured in one study [24]. It was measured by ICC and the children in the video distraction group demonstrated significantly higher anesthesia compliance than children who were accompanied by their parents.

The emergence delirium was measured in two studies [27] [30]. In both studies the authors used PAED to measure children emergence delirium and both studies included a premedication control group. When the emergence delirium was measured as a continuous variable the children in the video distraction group demonstrated a significantly lower level of emergence delirium than children who received premedication [30]. However, when the emergence delirium was measured as present or absent according to a cutoff point 10 and 12 the children in the video distraction group and other comparison groups did not 
differ significantly in the occurrence of emergence delirium [27] [30].

\subsection{Risk of Bias}

According to the Cochran risk of bias tool for the randomized clinical trial the eight reviewed studies were judged as low risk of bias in term of the reporting and attrition bias. The observers were not blinded to the outcome variable; therefore, the majority of studies were judged as having high detection bias. However, in term of performance bias the majority of studies were judged as having low risk of bias. Many studies were judged as non-clear in term of selection bias (Table $3)$.

\section{Discussion}

The data of the reviewed studies demonstrated that the children approach the day case surgery with high level of anxiety. To manage the high anxiety experiences of the children, many studies have evaluated the video distraction as anxiety alleviating intervention. Distraction is a nursing intervention that has a proved effectiveness in minimizing the patients' anxiety in various medical surgical and non-surgical procedures in a wide array of patients with different demographic characteristics.

In the past decade the effectiveness of video distraction intervention in minimizing the children preoperative anxiety has received the researchers' interest. The eight studies that we reviewed have demonstrated that video distraction was effective in reducing and controlling the high levels of children preoperative anxiety at different points along the surgical continuum. It was effective for a wide range of children; toddlers, preschoolers and school age children who underwent different types of, dental, ENT, eye, GI and genitourinary surgeries under general anesthesia. Compared with different pharmacological and nonpharmacological anxiety reduction interventions video distraction in the current review showed equal or superior effectiveness in minimizing children preoperative anxiety.

Table 3. Risk of bias of the reviewed studies.

\begin{tabular}{|c|c|c|c|c|c|c|}
\hline Author and year & $\begin{array}{c}\text { Random sequence } \\
\text { generation } \\
\text { (selection bias) }\end{array}$ & $\begin{array}{c}\text { Allocation } \\
\text { concealment } \\
\text { (selection bias) }\end{array}$ & $\begin{array}{c}\text { Blinding of } \\
\text { participants and } \\
\text { personnel } \\
\text { (performance bias) }\end{array}$ & $\begin{array}{l}\text { Blinding of } \\
\text { outcome } \\
\text { assessment } \\
\text { (detection bias) }\end{array}$ & $\begin{array}{c}\text { Incomplete } \\
\text { outcome data } \\
\text { (attrition bias) }\end{array}$ & $\begin{array}{l}\text { Selective reporting } \\
\text { (reporting bias) }\end{array}$ \\
\hline Patel et al., (2006) & Not clear & Not clear & Low risk & High risk & Low risk & Low risk \\
\hline Lee et al., (2012) & Low risk & Not clear & Low risk & High risk & Low risk & Low risk \\
\hline Mifflin et al., (2012) & Low risk & Low risk & Low risk & High risk & Low risk & Low risk \\
\hline Kerimoglu et al., (2013) & Low risk & Low risk & Low risk & High risk & Low risk & Low risk \\
\hline Seiden et al., (2014) & Not clear & Not clear & High risk & Low risk & Low risk & Low risk \\
\hline Kim et al., (2015) & Low risk & Not clear & Low risk & High risk & Low risk & Low risk \\
\hline Sola et al., (2017) & Low risk & Low risk & Low risk & High risk & Not clear & Low risk \\
\hline Marechal et al., (2017) & Low risk & Low risk & High risk & High risk & Low risk & Low risk \\
\hline
\end{tabular}


The majority of the reviewed studies included a pharmacological anxiety reduction comparison group. This is due to that premedication with midazolam and other anxiolytics is a common anxiety reduction intervention in Europe and United States of America [31]. However, using pharmacological anxiolytics to reduce children preoperative anxiety is controversial approach [27]. For example, Midazolam did not have a universal popularity because of the prolonged onset of effect and the probability of paradoxical effect which are agitation and restlessness [32]. Therefore, mounting amount of literature is directed toward evaluating the effectiveness of more safe nonpharmacological anxiety reduction alternatives [33]. In the current review, all studies that included a pharmacological anxiety reduction comparison supported that the video distraction alone can be a simple and safe alternative to pharmacological anxiety reduction approach alone or in combination with the video distraction.

Separation anxiety is a significant source of children preoperative anxiety at the surgical continuum [3]. Interestingly, the review showed that video distraction acted effectively on minimizing children separation anxiety. Many studies came out with that compared with pharmacological anxiolytics video distraction have a similar anxiolytic effect on children parental separation anxiety [23] [27] [28]. However, Seiden [30] had a conflicting finding; video distraction was superior to premedication in reducing the children parental separation anxiety. All of These studies employed mYPAS to measure the children preoperative anxiety; however, Seiden [30] study differed in that it included children younger than two years old, the other studies involved older children ( $>4$ years old). It has been reported that mYPAS is less reliable in measuring the anxiety of children less than 4 years [28].

Parental presence during anesthesia induction is another common and yet a controversial anxiety reduction strategy [32]. When the combined video distraction and parental presence intervention was compared with parental presence only intervention the authors came out with different conclusions. The authors of one study found that the video distraction have no additional anxiolytic effect on the parental presence [24] while others found that the video distraction added to the parental presence anxiolytic effectiveness [29]. They found that combined video distraction and parental presence intervention was superior to parental presence alone in minimizing children anxiety [29]. Kim et al. [24] have used a passive video distraction intervention where the children watched a film while Patel et al. [29] used active video distraction where the children played a video game. It has been claimed that the active component of distraction which involve motor and mental activity is the effective one. It was assumed previously that the passive distraction activities would not be as effective as interactive ones [29]. Countering this assumption, subsequent clinical trials have supported the effectiveness of passive video distraction [24] [27]. However, yet, no studies have been found that aimed to compare passive and interactive audiovisual distraction. 
Compared with parental presence intervention the video distraction intervention revealed a superior effectiveness on minimizing children parental separation anxiety [24]. This finding suggests that the parental presence might not be the best practice to control the children separation anxiety in the situation of surgery. However, since many institutions have the parental presence during anesthesia induction embedded in their preoperative preparation routine; yet, additional studies are required to reach a conclusion about the best preoperative anxiety management practice.

Video distraction intervention has demonstrated superior effectiveness in minimizing children anxiety over the usual standard preoperative preparation at the time of anesthesia induction and at the parental separation [25]. However, compared with distraction using traditional toys video distraction effectiveness varied on different points of time. Video game distraction was superior at the time of anesthesia induction; however, traditional toys distraction was more effective in minimizing children anxiety at the holding area while waiting for surgery [25]. Further studies are needed to conclude evidence about this finding.

Despite of that all eight studies used mYPAS, the studies varied in the approach to calculate the end point score and in the robustness of the data collection process. Some authors have reported the difference between the children baseline anxiety and their anxiety at the time of anesthesia induction or parental separation as the primary outcome. Others have compared the children preoperative anxiety at a single point of time as a primary outcome. This in turn might lead to different conclusions about the anxiolytic effectiveness of video distraction. The variation in the children level of anxiety among the studies at different points of time and the conflicting findings might be also explained, in part, by the differences in the observers level of training and experience.

The studies' findings might also vary as a result of the variation in the preoperative preparation routines in the studies settings. For example in Sola et al. [27] the children had low baseline anxiety levels $(<30$; the cutoff point of $\mathrm{mY}$ PAS) because of the preoperative preparation program that the children underwent before the day of surgery as a part of the study setting routine. Despite of these variations, the review findings reinforce that there is anxiety reduction effectiveness of video distraction intervention.

During the induction of anesthesia children high level of anxiety might affect the child induction compliance [34]. Children with higher level of anxiety exhibit poorer behavioral compliance during anesthesia induction than children with lower level of anxiety [34]. Postoperatively high level of anxiety is associated with high incidence of emergence delirium and maladaptive behavioral responses [35]. However, there was inadequate evidence about the effectiveness of video distraction on pre and postoperative markers of anxiety including anesthesia induction compliance and emergence delirium.

Overall, observational studies where the observers are not blinded to the intervention carry high observational and detection bias. This is why that the majority of studies in the current review were evaluated as having high risk of ob- 
servation and detection bias. However, despite of that children were not blinded to the intervention the majority was not judged as high in term of performance bias. We believe that children of the age from $1-12$ will not change their behavior when they are observed in a critical anxiety provoking moments such as parental separation and anesthesia induction moments. As a result of the inadequacy of describing the randomization technique in the research reports in term of participants' allocation and concealment many studies were judged as having no clear risk of selection bias.

\section{Limitations}

The eight studies were performed in three countries: USA, South Korea and France which can limit the review findings generalizability to children from other cultures. Additionally, the studies included children from age of $1-12$; this in turn limit the generalizability of the findings to older children. Despite of that the effectiveness of the intervention was supported in all studies the variation in the duration of distraction before the anesthesia induction and the variation in the tools of administrating the distraction prohibit reaching a conclusion regarding the therapeutic use of distraction. The studies were characterized by high risk of observer and detection bias; therefore; it is recommended to implement robust observation methods through adequate training of the observers. Reporting the appropriate interrater reliability index in future studies of this kind is also recommended.

\section{Recommendations}

Because of the studies limitations and inconsistency in findings, additional research is needed to determine the effect of video distraction intervention on emergence delirium and anesthesia induction compliance in anxious preoperative children. Research studies are also needed to further investigate the differences in self-selected video game or film and researcher selected video game or film in minimizing anxiety in children preoperative anxiety. Research should also focus on determining the most therapeutic duration of video distraction needed for decreasing high levels of anxiety. Research studies that compare the anxiolytic effect of active and passive video distraction are also recommended. Moreover, researches that evaluate the effect of video distraction intervention in other European, African and Asian children from different cultures is also recommended.

The review supported that video distraction is a safe and cost effective anxiolytic intervention. Therefore, it is convenient for nurses to apply within the rapid pace working rhythm environment of the day case surgery departments. Allowing the child to select their preferred game or film might enhance their control over the situation.

\section{Conclusion}

The purpose of the current review was to assess the effect of video distraction 
intervention in decreasing anxiety among children who underwent a day case surgery under general anesthesia and to present the current state of knowledge in relation to the use of video distraction intervention as an effective nursing intervention in the preoperative setting. Video distraction is effective and time saving anxiolytic intervention and can be used safely by the nurses to minimize children preoperative anxiety within the context of day case surgery. However, further studies are needed to reach an agreement about the best practice regarding the use of video distraction to control children preoperative anxiety.

\section{References}

[1] Draskovic, B., Simin, J.M. and Kvrgic, I.M. (2015) Psychological Aspects of Pediatric Anesthesia. Medicinski Pregled, 68, 29-34. https://doi.org/10.2298/MPNS1502029D

[2] Fortier, M.A., Del Rosario, A.M., Martin, S.R. and Kain, Z.N. (2010) Perioperative Anxiety in Children. Paediatric Anaesthesia, 20, 318-322. https://doi.org/10.1111/j.1460-9592.2010.03263.x

[3] Banchs, R.J. and Lerman, J. (2014) Preoperative Anxiety Management, Emergence Delirium, and Postoperative Behavior. Anesthesiology Clinics, 32, 1-23. https://doi.org/10.1016/j.anclin.2013.10.011

[4] Harris, T.B., Sibley, A., Rodriguez, C. and Brandt, M.L. (2013) Teaching the Psychosocial Aspects of Pediatric Surgery. Seminars in Pediatric Surgery, 22, 161-166. https://doi.org/10.1053/j.sempedsurg.2013.05.005

[5] Beringer, R.M., Segar, P., Pearson, A., Greamspet, M. and Kilpatrick, N. (2014) Observational Study of Perioperative Behavior Changes in Children Having Teeth Extracted under General Anesthesia. Paediatric Anaesthesia, 24, 499-504. https://doi.org/10.1111/pan.12362

[6] Chieng, Y.J.S., Chan, W.C.S., Liam, J.L.W., Klainin-Yobas, P., Wang, W. and He, H.G. (2013) Exploring Influencing Factors of Postoperative Pain in School-Age Children Undergoing Elective Surgery. Journal for Specialists in Pediatric Nursing, 18, 243-252. https://doi.org/10.1111/jspn.12030

[7] Fortier, M.A., Del Rosario, A.M., Rosenbaum, A. and Kain, Z.N. (2010) Beyond Pain: Predictors of Postoperative Maladaptive Behavior Change in Children. Paediatric Anaesthesia, 20, 445-453. https://doi.org/10.1111/j.1460-9592.2010.03281.x

[8] Draskovic, B., Stanic, D., Uram-Benka, A. and Fabri, I. (2014) Stress Indicators during General Anesthesia with Opioid Analgesics in Children. Turkish Journal of Medical Sciences, 44, 1095-1102. https://doi.org/10.3906/sag-1305-36

[9] Manyande, A., Cyna, A.M., Yip, P., Chooi, C. and Middleton, P. (2015) Non-Pharmacological Interventions for Assisting the Induction of Anaesthesia in Children (Review). Cochrane Database of Systematic Reviews, 7, 1-122. https://doi.org/10.1002/14651858.CD006447.pub3

[10] Kain, Z.N., Caldwell-Andrews, A.A., Mayes, L.C., Weinberg, M.E., Wang, S.-M., MacLaren, J.E. and Blount, R.L. (2007) Family-Centered Preparation for Surgery Improves Perioperative Outcomes in Children. Anesthesiology, 106, 65-74. https://doi.org/10.1097/00000542-200701000-00013

[11] Gao, X.L., Liu, Y., Tian, S., Zhang, D.Q. and Wu, Q.P. (2014) Effect of Interesting Games on Relief of Preoperative Anxiety in Preschool Children. International Journal of Nursing Sciences, 1, 89-92. https://doi.org/10.1016/j.ijnss.2014.02.002

[12] Fortier, M.A. and Kain, Z.N. (2015) Treating Perioperative Anxiety and Pain in 
Children: A Tailored and Innovative Approach. Paediatric Anaesthesia, 25, 27-35. https://doi.org/10.1111/pan.12546

[13] Koller, D. and Goldman, R.D. (2012) Distraction Techniques for Children Undergoing Procedures: A Critical Review of Pediatric Research. Journal of Pediatric Nursing, 27, 652-681. https://doi.org/10.1016/j.pedn.2011.08.001

[14] Traeger, L. (2013) Distraction (Coping Strategy) BT. In: Gellman, M.D. and Turner, J.R., Eds., Encyclopedia of Behavioral Medicine, Springer, New York, 610-611. https://doi.org/10.1007/978-1-4419-1005-9_179

[15] Voepel-Lewis, T. (2017) New Era for an Age-Old Problem? Reducing Parental and Child Anxiety through Technology. Journal of PeriAnesthesia Nursing, 31, 552-554. https://doi.org/10.1016/j.jopan.2016.08.009

[16] McQueen, A., Cress, C. and Tothy, A. (2012) Using a Tablet Computer during Pediatric Procedures a Case Series and Review of the "Apps." Pediatric Emergency Care, 28, 712-714. https://doi.org/10.1097/PEC.0b013e31825d24eb

[17] Chow, C.H.T., Van Lieshout, R.J., Schmidt, L.A., Dobson, K.G. and Buckley, N. (2016) Systematic Review: Audiovisual Interventions for Reducing Preoperative Anxiety in Children Undergoing Elective Surgery. Journal of Pediatric Psychology, 41, 182-203. https://doi.org/10.1093/jpepsy/jsv094

[18] Primack, B.A., Carroll, M.V., McNamara, M., Klem, M.Lou, King, B., Rich, M., Nayak, S., et al. (2012) Role of Video Games in Improving Health-Related Outcomes: A Systematic Review. American Journal of Preventive Medicine, 42, 630-638. https://doi.org/10.1016/j.amepre.2012.02.023

[19] Al Mahdali, G.A. (2015) Interventions for Preoperative Children's Anxiety. Journal of Anesthesia \& Critical Care, 2, Article ID: 00044.

[20] Hutton, B., Salanti, G., Caldwell, D.M., Chaimani, A., Schmid, C.H., Cameron, C., Moher, D., et al. (2015) The PRISMA Extension Statement for Reporting of Systematic Reviews Incorporating Network Meta-Analyses of Health Care Interventions: Checklist and Explanations. Annals of Internal Medicine, 162, 777-784. https://doi.org/10.7326/M14-2385

[21] Fineout-Overholt, E. and Johnston, L. (2005) Teaching EBP: Asking Searchable, Answerable Clinical Questions. Worldviews on Evidence-Based Nursing, 2, 157-160. https://doi.org/10.1111/j.1741-6787.2005.00032.x

[22] Higgins, J. and Green, S. (2011) Cochrane Handbook for Systematic Reviews of Interventions. The Cochrane Collaboration, London.

[23] Kerimoglu, B., Neuman, A., Paul, J., Stefanov, D.G. and Twersky, R. (2013) Anesthesia Induction Using Video Glasses as a Distraction Tool for the Management of Preoperative Anxiety in Children. Anesthesia and Analgesia, 117, 1373-1379. https://doi.org/10.1213/ANE.0b013e3182a8c18f

[24] Kim, H., Jung, S.M., Yu, H. and Park, S.-J. (2015) Video Distraction and Parental Presence for the Management of Preoperative Anxiety and Postoperative Behavioral Disturbance in Children: A Randomized Controlled Trial. Anesthesia and Analgesia, 121, 778-784. https://doi.org/10.1213/ANE.0000000000000839

[25] Lee, J., Lee, J., Lim, H., Son, J.-S., Lee, J.-R., Kim, D.-C. and Ko, S. (2012) Cartoon Distraction Alleviates Anxiety in Children during Induction of Anesthesia. Anesthesia and Analgesia, 115, 1168-1173. https://doi.org/10.1213/ANE.0b013e31824fb469

[26] Mifflin, K.A., Hackmann, T. and Chorney, J.M. (2012) Streamed Video Clips to Reduce Anxiety in Children during Inhaled Induction of Anesthesia. Anesthesia and Analgesia, 115, 1162-1167. https://doi.org/10.1213/ANE.0b013e31824d5224 
[27] Sola, C., Lefauconnier, A., Bringuier, S., Raux, O., Capdevila, X. and Dadure, C. (2017) Childhood Preoperative Anxiolysis: Is Sedation and Distraction Better than Either Alone? A Prospective Randomized Study. Paediatric Anaesthesia, 27, 827-834. https://doi.org/10.1111/pan.13180

[28] Marechal, C., Berthiller, J., Tosetti, S., Cogniat, B., Desombres, H., Bouvet, L., De Queiroz Siqueira, M., et al. (2017) Children and Parental Anxiolysis in Paediatric Ambulatory Surgery: A Randomized Controlled Study Comparing $0.3 \mathrm{mg} / \mathrm{kg} \mathrm{Mi}$ dazolam to Tablet Computer Based Interactive Distraction. British Journal of Anaesthesia, 118, 247-253. https://doi.org/10.1093/bja/aew436

[29] Patel, A., Schieble, T., Davidson, M., Tran, M.C.J., Schoenberg, C., Delphin, E. and Bennett, H. (2006) Distraction with a Hand-Held Video Game Reduces Pediatric Preoperative Anxiety. Paediatric Anaesthesia, 16, 1019-1027. https://doi.org/10.1111/j.1460-9592.2006.01914.x

[30] Seiden, S.C., McMullan, S., Sequera-Ramos, L., De Oliveira, G.S., Roth, A., Rosenblatt, A., Suresh, S., et al. (2014) Tablet-Based Interactive Distraction (TBID) vs Oral Midazolam to Minimize Perioperative Anxiety in Pediatric Patients: A Noninferiority Randomized Trial. Paediatric Anaesthesia, 24, 1217-1223. https://doi.org/10.1111/pan.12475

[31] Abdallah, C. and Hannallah, R. (2011) Premedication of the Child Undergoing Surgery. Middle East Journal of Anesthesiology, 21, 165-176.

[32] O’Sullivan, M. and Wong, G.K. (2013) Preinduction Techniques to Relieve Anxiety in Children Undergoing General Anaesthesia. Continuing Education in Anaesthesia Critical Care \& Pain, 13, 196-199. https://doi.org/10.1093/bjaceaccp/mkt014 http://search.ebscohost.com/login.aspx ?direct=true \&db=asn\&AN=92051354\&site $=$ eds-live

[33] Capurso, M. and Ragni, B. (2016) Psycho-Educational Preparation of Children for Anaesthesia: A Review of Intervention Methods. Patient Education and Counseling, 99, 173-185. https://doi.org/10.1016/j.pec.2015.09.004

[34] Cui, X., Zhu, B., Zhao, J., Huang, Y., Luo, A. and Wei, J. (2016) Parental State Anxiety Correlates with Preoperative Anxiety in Chinese Preschool Children. Journal of Paediatrics and Child Health, 52, 649-655. https://doi.org/10.1111/jpc.13176

[35] Kain, Z.N., Caldwell-Andrews, A.A., Maranets, I., McClain, B., Gaal, D., Mayes, L. C., Zhang, H., et al. (2004) Preoperative Anxiety and Emergence Delirium and Postoperative Maladaptive Behaviors. Anesthesia and Analgesia, 99, 1648-1654.

https://doi.org/10.1213/01.ANE.0000136471.36680.97 